\title{
Reconsidering Regional Retailing 地域商業を再考する
}

\author{
Junya Ishibuchi ${ }^{* 1}$ \\ 編集委員 / 関西学院大学 商学部 教授 \\ 石淵順也
}

${ }^{* 1}$ Editor and Professor, School of Business Administration at Kwansei Gakuin University, cas86311@kwansei.ac.jp

\begin{abstract}
There are two purposes of this special issue. The first is to introduce the current state of local commerce and new activities, to define the associated problems, and to provide opportunities to think about solutions. We hope that this special issue will inform readers on both the positive and negative aspects of current regional commerce and will promote thoughts and ideas on commerce and town development. The second is promotion of academic research. Rather than focus only on new phenomena, there is an opportunity for researchers to think about the underlying mechanisms and problems. Through this process, we hope to see further progress in regional commercial research.
\end{abstract}

地域商業は，これまでとは違う段階に入ったのかもしれない。これにはポジティブ，ネガティブ両方の 意味がある。まず，ややネガティブな話から始めたい。

地域商業に関しては，これまでも多くの報道や学術論文などがあり，地域商業の一形態である商店街の 厳しい現状や，地域貢献活動などが取り上げられてきた。しかし，商店街が立ち行かなくなったとき，担っ てきた「まち」のインフラの維持・管理，処分をどうするかついては，ほとんど注目を集めることはなかっ た。しかも，「まち」のインフラは老朽化が進んでいることが多いが，老朽化という点にもあまり注目は集 まっていない。これは, 野村総研 ${ }^{1)}$ がインフラ老朽化の 2030 年問題を指摘して以降, 橋, 道路などのイン フラの老朽化に注目が集まるのとは対照的である。

しかし, 今, 中心商業地のインフラ老朽化は, 重要な問題となっている。これまで, 商店街などの地域 商業者や商店街組織が中心商業地のインフラとも言える都市施設（アーケード, 駐車場, ポケットパーク, 共同ビルの一部など）の所有と管理を担うことが多かったが, Ishihara（2014）によれば，経営難に陥った 商店街振興組合から行政がアーケードを買い取ることや，立体駐車場を保有する商店街振興組合が破たん するなどの事態が生じている。また，Watanabe（2018）は，1950 年代から 1960 年代にかけて，耐火建築 法や防災建築街区造成法により建築された共同ビルなどの老朽化問題を取り上げ，「老朽化した共同建築物 等が一定規模以上に集積している都市においては，それらを放置するとまちづくりの障害になりかねない ため，取り壞して再開発するか，あるいは耐震補強等の補修を含むリノベーションによって当面使い続け るかが，まちづくりの大きな課題になってきている」（p.96）と指摘している。商業の共同ビルは都市施 設なのかという疑問は当然でると思われるが，例えば沼津市のアーケード名店街などでは，共同ビル建築 時に商店がセットバックし， 2 階部分が歩道側にせり出しアーケードの役割をしているケースもある。ま た，共同ビルは，その上層階に公営住宅が整備されることや，道路沿いに長い共同ビルを建築することで 防火壁の役割を果たすことなどがあり，商売以外の「まち」の機能を担っているケースも多い。

まちの住人が利用する都市施設の一部を，地域商業者や商店街組織が借金をしてまで整備，保有してき たのだが，それを維持できなくなった時，誰がどのように維持管理，あるいは処分するのか。上述の研究 者達の指摘は, 中心商業地のインフラ・都市施設の整備時には想定していなかったこの問題を, 真剣に考 
え始める時期に来ていることを示している。今後, この傾向は増えることこそあれ, 減ることはないと考 えられるが，この問題にどう対処するか，誰もスキームを準備できていないのが現状である。

もう一つ違う段階に入ったかもしれないと考える点は, ポジティブな面である。いくつかの商店街が「商 店」の「街（まち)」にこだわらなくなってきている点である。例えば, Sumiya, Watanabe, and Niijima (2018) によれば，北海道の発寒北商店街は，物販の商店街からサービス中心の商店街への移行をめざし，「どんな 悩みも解決できる相談空口」を設け，住民の生活の悩みを解決する場になることを目指している。平成 27 年度商店街実態調查の報告書によれば, 商店街の物販店の比率は $40.5 \%$ あり, サービス店や飲食店など の非物販店が増えている。物販店が立ち行かなくなり，サービス店などが出店しているということである が，これは必ずしもネガティブなことではないかもしれない。J.フロントリテイリングの元 CEO 兼会長の Okuda（2014）は，呉服店の一部は百貨店に生まれ変わったことで生き残ったが，「変化に対応できなかっ たことで数えきれないほどの呉服店が消えていったはず」(p. 4) であると言っている。1つの小売企業と, 自然発生的な商店の集まりである商店街を同列に論じることはできないが, どのような組織も生き残るた めには，程度の差こそあれ変化に対応することが必要である。そのためには，マーケティング・マイオピ ア的にモノの販売にこだわらず, 住民が本当に求めているサービスの提供を目指すというのは, 新しい変 化への対応の 1 つの形であろう。

本特集の目的は，大きく 2 つある 1 つ目は，地域商業の現状や新たな取り組みを広く紹介し，その問 題を整理し，選択肢を考える機会を提供するという点である。本特集が，地域商業のポジティブ，ネガティ ブ両方の現状を少しでも知る機会となり，地域商業やまちづくりの問題を考える機会となればと考えてい る。2つ目は, 学術的研究の促進である。新しい現象にだけとらわれるのではなく, 多くの研究者の方に とって, その背後にあるメカニズムや問題点を考える機会となり, 地域商業研究がより進展することを願っ ている。

本特集は 2 部から構成されている。前半は，マクロ視点の地域商業，政策に関する論文であり，第 1 , 2 論文が該当する。後半は，ミクロ視点の事例を中心とする論文であり，第 $3 ， 4 ， 5$ 論文が該当する。

第 1 論文は，石原武政氏による「小売業の外部性と地域貢献」である。石原氏は，小売業の外部性に関 する詳細な考察に基づき，小売業の社会貢献と地域貢献について検討を行っている。中小小売商がこれま で担ってきた地域貢献の位置づけと，大型小売店に社会貢献が求められるようになった経緯を紐解き，中 小小売商が行っている地域貢献に，チェーン型大型店が参画することの重要性を指摘している。

第 2 論文は，渡辺達朗氏による「イギリスに扔ける都市再生の思想・政策・取組み一小売・サービス等 の多様性と持続可能性の視点から日本への示唆を探る一」である。渡辺氏は，イギリスの都市政策の思想, 政策，取組みの検討から，多様性，複合用途，持続可能性という評価軸の重要性を指摘している。また， これらの評価軸に基づき，日本の都市政策，まちづくりの問題点を明快に指摘している。

第 3 論文は，西村順二氏による「ボランタリーチェーンがもたらす地域商業に対する有効性一コスモ ス・ベリーズの事例に基づく流通再考一」である。西村氏は, 日本の小売業と卸売業の動態的変化の詳細 な検討から，卸売業と小売業の連関に関する問題を指摘している。このような中で，地域の小売業を支援 しながら，自らの成長も目指すボランタリーチェーンの事例を取り上げ，変わりゆく流通の世界を理論的 に検討している。

第 4 論文は，二宮麻里氏・濱満久氏による「独立零細小売商による経験価值の提供」である。二宮氏・ 濱氏は，地域商業者の大きな割合を占める零細小売商の「生産局面にまで踏み込んだ仕入活動」をケース に基づき理論的に検討している。零細小売商は，その接客や地域貢献の独自性に注目が集まりがちだが, 
本論文は，零細小売商が積極的な生産段階に介入し，差別的な品揃えを形成し，消費者に優れた経験価值 を提供する様子を生き生きと捉えている。現象だけでなく, それを分析する両氏の理論的視座にご注目頂 きたい。

第 5 論文は，山口信夫氏による「衰退商業地における新規開業事例に関する研究一松山市三津地区にお けるワークライフバランス事業者を事例にして一」である。山口氏は, 衰退する商業地のワークライフバ ランス事業のビジネスモデルを，ヒアリング調査を中心に丁寧に掘り下げ，地域商業の再生の方策を検討 している。ワークライフバランス事業者が，不動産価格の下落を積極的に利用し，関与度の高い消費者を 広域から集客する様子を，個店の損益分岐点にまで踏み込み，検討を行っている。

これまでとは異なる段階に本当に入ったのかどうかは，時間が経ち振り返った時にしか分からない。た だ，買物難民問題にも注目が集まる昨今，すべての人がこの問題を真剣に考えるべき時期に来ていること は間違いないだろう。論文にお目通し頂き，この問題を考えるきっかけにして頂ければ幸いである。

\section{注}

1）文献として, Ohnuma, Okamura, Kobayashi, Mizuishi, and Deguti（2015）が挙げられる。

\section{References}

Ishihara, T. (2014). Syoutengai no hudousan to syoutengai sosiki: Jou. The Journal of Marketing and Distribution, 509, 44-57.（石原武政（2014）。「商店街の不動産と商店街組織」『流通情報』509, 44-57.）(In Japanese)

Ohnuma, K., Okamura, A., Kobayashi, Y., Mizuishi, T., and Deguti, M. (2015). 2030 nen no nihon ga cyokumen suru kouzouteki kadai. Knowledge Creation and Integration. 2015-04. 6-19.（大沼健太郎，岡村篤，小林庸至，水石 仁, 出口満 (2015).「2030 年の日本が直面する構造的課題」『知的資産創造』2015 年 4 月号. 6-19.) (In Japanese)

Okuda, T. (2014). Mikan no ryutsu kakumei. Tokyo: Nikkei BP. (奥田務（2014）。『未完の流通革命一大丸松坂屋，再 生の 25 年』日経 BP 社. ) (In Japanese)

Sumiya, Y., Watanabe, T., and Niijima, Y. (2018). Tiiki needs ni kotaeru syoutengai. Ishihara, T. and Watanabe, T. (Eds.). Kourigou kiten no matidukuri. Tokyo: Sekigakusya, 140-156. (角谷嘉則・渡辺達朗・新島裕基（2018）。「地域 ニーズに応える商店街」, 石原武政・渡辺達朗編『小売業起点のまちづくり』碩学社. 140-156. ) (In Japanese)

Watanabe, T. (2018). Numadu arcade meitengai no kensetsu kara saikaihatsu madeno keii to tenbou: Boukakentikutai tositeno tempo heiyou kyoudou jutaku kara life style center he. Commercial Review of Senshu University, 106, 95116.（渡辺達朗 (2014)。「沼津アーケード名店街の建設から再開発までの経緯と展望一防火建築帯としての 店舗併用共同住宅からライフスタイルセンターへ」『専修商学論集』106, 95-116.) (In Japanese) 